\title{
Countermeasures to Enhance Heilongjiang Agricultural International Competitiveness Based on the Open Economy
}

\author{
Yanming $\mathrm{Hou}^{1,2, a}$ and Zhen Guo ${ }^{1, b}$ \\ ${ }^{1}$ Harbin University of Commerce, China; \\ ${ }^{2}$ HeiLongjiang Agricultural Engineering Vocational College, China \\ ahouyanming66@163.com, bguozhenhrb@163.com
}

Keywords: Open economy; International competitiveness; Research of mechanism; Competitiveness index

\begin{abstract}
Heilongjiang agriculture has been occupies an important position in China. Green food and commodity grain base and north barn are both its laudatory titles. However, Heilongjiang agriculture does not have high international competition ability and lacks brand effect. In an open market environment, Heilongjiang agriculture actively adapts to the new normal agriculture, seek to develop in the international competition, looks for the inside power and deeply implement "introduct to and go out" two-way trajectory. It also overall plans both international and national "two markets, two resources and two types of rules" and speeds up the development ofan open agriculture to enhance heilongjiang agricultural international competitiveness.
\end{abstract}

\section{Introduction}

The soil of Heilongjiang province is one of only three pieces black soil in China currently. Heilongjiang province has abundant agricultural natural resources and advantages in the soil resources. It borders with Russia, North Korea, Japan and South Korea. Due to geographical reasons, Russia, South Korea and Japan have been the main agricultural export destination countries of Heilongjiang agricultural products. Heilongjiang total grain output reached 68.479 billion kilograms in 2015. Agriculture international competition is mainly agricultural products competition. A large amount agricultural commodities exports including canned and other (16.5\%) and animal by-products, honey, fruit $(38.5 \%)$ is the main part of the Heilongjiang agricultural products export and nearly occupies the half of the whole province agricultural exports. Double exports of agricultural products are grains and grain powder, dried chili, fresh frozen beef, live fish and natural honey and so on. Exports of soybeans, edible fungus and medicinal herbs decrease. Among them, Russia keeps the largest proportion of the total exports of agricultural products in heilongjiang province. The exports of agricultural products to Russia can be accounted for half of the Heilongjiang overall agricultural exports. The second is South Korea. Because of the increase of the Japanese imported agricultural products technical limitations, heilongjiang province agricultural exports to Japan decreases. And the export target countries decide the exports of agricultural products in heilongjiang province have the high dependence and also led to the increasing effects of technical barriers to agricultural exports in heilongjiang province.

Heilongjiang unique green food does not have the advantages of dominant in the international competition. In 2015, heilongjiang province certificate 15000 kinds of products as green food, organic food or pollution-free agricultural products. The products include grains, vegetables, fruits, drinks, aquatic products, livestock, poultry, eggs, milk, oil and other 14 kinds of products. Among all the products, food accounted for $67.5 \%$ of the total, livestock and poultry products accounted for $22.5 \%$, aquatic products accounted for $0.3 \%$, drink class accounted for $7.0 \%$ and other products accounted for $2.7 \%$. Therefore, our province green product structure is unreasonable. There are too much food exports, the low proportion of multivariate economic crops. It is unable to adapt to the residents' diversified consumer demand.

China business yearbook defines the main agricultural exports as agricultural exports which the value are more than $\$ 10$ million. In heilongjiang province, from 2001 to 2012 there are six kinds of 
agricultural products' export value over $\$ 10$ million. They are rice, corn, fresh apple, soybeans, frozen pork and flue-cured tobacco. This article bases on these six kinds of agricultural products evaluates the international competitiveness of heilongjiang province agricultural products (shown in Table 1 and Fig. 1)

Table 1 The Amount of the Heilongjiang Main Agricultural Products' Export (2004-2012)

\begin{tabular}{|l|l|l|l|l|l|l|}
\hline \multicolumn{1}{|c|}{ Year } & \multicolumn{1}{|c|}{ Rice } & \multicolumn{1}{c|}{ Corn } & \multicolumn{1}{c|}{$\begin{array}{c}\text { Fresh } \\
\text { apple }\end{array}$} & \multicolumn{1}{c|}{ Soybean } & $\begin{array}{c}\text { Frozen } \\
\text { pork }\end{array}$ & \multicolumn{1}{c|}{$\begin{array}{c}\text { Flue-cured } \\
\text { tobacco }\end{array}$} \\
\hline 2004 & 3860.59 & 2917.7 & 1869.99 & 3164.3 & 6716.3 & 1496.64 \\
\hline 2005 & 3870.93 & 14314.7 & 2293.63 & 2367.94 & 7733.71 & 1633.96 \\
\hline 2006 & 6110.13 & 2257.63 & 2988.78 & 1436.21 & 10802.99 & 1409.17 \\
\hline 2007 & 2004.97 & 4584.14 & 4697.34 & 1165.74 & 4784.36 & 1393.06 \\
\hline 2008 & 2120.72 & 0 & 7211.65 & 9194.75 & 769.83 & 1520.76 \\
\hline 2009 & 2825.54 & 15.32 & 6094.63 & 1824.88 & 303.41 & 2123.9 \\
\hline 2010 & 2944 & 5.08 & 5119.14 & 1288.8 & 571.12 & 1511.03 \\
\hline 2011 & 2871 & 0 & 4614.2 & 507 & 632.9 & 1504 \\
\hline 2012 & 2988 & 0 & 4676.6 & 2049.4 & 348 & 1270 \\
\hline 2013 & & & & & & \\
\hline 2014 & & & & & & \\
\hline
\end{tabular}

Datasource: China Agriculture Yearbook (2004-2015) and heilongjiang yearbook(2004-2015)

It is shown that in Table 1 and Fig. 1 the export amounts of the rice, fresh apple an flue-cured tobacco in heilongjiang province from 2001-2014 remains at more than \$10 million. It closely related to agricultural development policy in heilongjiang province. Amongthese six kinds of products, the exports of fresh apple maintain a fast growth momentum, while the exports of corn show a volatile situation and appeare zero exports in individual years. The exports of soybeans and frozen pork is not stable as well and appeare a downward trend. However, the amplitude of variation is less the corn's. The emergence of this phenomenon can be attributed to heilongjiang province agricultural product added value is low, the quality of the product is not in conformity with the international quality certification standards and the low level of processing scale.

\section{Heilongjiang Agricultural International Competitiveness Factors Analysis under the Open Economy.}

This article selects revealed comparative advantage index, TC index and the contribution rate of exports to measure and analysis heilongjiang agricultural and put forward corresponding countermeasures.

Revealed Comparative Advantage Index. Due to the international market is often impacted by non-economic factors such as geography, history and politics, some countries' (regions') one product export to these industrial developed countries (regions) have an advantage or the market occupancy rate is high. It is shown that the country of this kind of product has a strong international competitiveness. The formula is as follows:

\section{RCAij $=($ Xij /Xit $) /($ Xwj /Xwt $)$}

Among them, the RCAij revealed comparative advantage index, Xij is the total amount of a country or a region (j) product export. Xwj is the world's total export amount of the product $\mathrm{j}$. Xi is the export amount of the the whole world's product $\mathrm{j}$. Xw is the total export amount of the the whole world's product. This formula is usually measured in time. When RCAij $\geq 1$, it is shown that $\mathrm{j}$ products has the revealed comparative advantage in this country. The advantages will be more obvious with the increase of the RCAij. When the RCAij $<1$, j products does not have the revealed comparative advantage in this country. The disadvantages will be more obvious with the decrease of the RCAij. 
The RCAij of all the agricultural products in heilongjiang province is bigger than 1 from 2004 to 2006. It is shown that the agricultural products in heilongjiang province has the obvious revealed comparative advantage. However, only in 2003, the RCA index is higher than 2.5. In other years, the RCA index is always declining, and the comparative advantage is gradually decline. From 2007, the RCAij of the heilongjiang province agricultural products is always smaller than 1. Heilongjiang agricultural international competitiveness is weak, and the comparative advantage is gradually lost.

Competitiveness Index. This metric mainly refers to a country or region net exports of some products and the ratio of the total amount of this product import and export. The formula is as follows:

TCit $=($ Xit - Mit $) /($ Xit + Mit $)$

TCit is the competitiveness index of one kind of product in a country or a region. Xit - Mit is The net exports of the products in a country or a region. Xit + Mit is the total amount of the product's import and export in a country or a region. The competitiveness index of one kind of product in a country or a region is always between -1 and 1 . When the competitiveness index tends to -1 , this kind of product in a country or a region has less competitiveness. Otherwise, when the competitiveness index tends to 1, this kind of product in a country or a region has stronger competitiveness. When the $\mathrm{TCit}=0$, this kind of product in a country or a region has no comparative advantage, even has disadvantages. And the production efficiency of this kind of product in a country or a region belows the international level. When $0 \leq \mathrm{TCit} \leq 1$, the production efficiency of this kind of product in a country or a region higher than the international level, and this kind of product has the comparative advantages and stronger international competitiveness. When the TCit $=0$, this kind of product in this country has no export and completely relies on imports. When the TCit=1, this kind of product in this country has the absolute predominance and do not be imported.

From 2004 to 2014, the TC index of heilongjiang province agricultural products international competitiveness is always bigger than 0. Although the fluctuation is bigger in individual years, the overall level is high and were bigger than 0.4 . This shows that heilongjiang province has the strong international competitiveness of agricultural products. Agricultural production efficiency have strong comparative advantage as a whole. However, from 2009, trade competitiveness index is less than 0 , the agricultural products keep a poor international competitive force. There is a big disadvantage in the face of fierce market competition.

The Contribution Rate of Exports. This metric is the ratio of exports of a product in a country or a region accounted for the country's total exports. The formula is as follows:

\section{$\mathrm{Ci}=\mathrm{Xi} / \mathrm{X}$}

$\mathrm{Ci}$ is the contribution rate of exports of the product $\mathrm{i}$. $\mathrm{Xi}$ shows a product exports in a country or a region. X is the country's total exports. From 2004 to 2014, the agricultural export contribution rate is in the overall downward trend in heilongjiang province and the nationwide. However, the contribution rate of exports in heilongjiang province is higher than the national level. Heilongjiang province agricultural products export contribution rate has reached the $23.22 \%$ of record levels in 2004. From 2004 to 2012, the decline of the agricultural products export contribution rate in heilongjiang province is accelerated significantly. It is mainly influenced by international market competition and the international financial crisis. Therefore, overall, although the heilongjiang province agricultural products export contribution rate fell, this fell below the overall decline, agricultural exports still showed a modest growth trend.

\section{Countermeasures to Enhance Heilongjiang Agricultural International Competitiveness under the Open Economy}

Strengthening Agricultural "Go out" and "the Belt and Road Initiatives" Strategic Top-Level Design. To create an overall development plan for the agricultural "go out". The major industry, nationality, area, project and some other factors should be cleared. "go out" should be combined with "the Belt and Road Initiatives" to avoid the cutthroat competition and establish the complete 
information service platform. It can promote the global agricultural cooperation and transfer between heilongjiang province and the countries along "the Belt and Road Initiatives", guarantee domestic grain security and the sustainable and steady supplyment of the industrial raw materials.

Establish the Open Agricultural Demonstration Zones. The government should establish the open agricultural demonstration zones in the border cities of heilongjiang province and supply the policies support. The production base should be built aiming at target market to strengthen the product competitiveness. On the other hand, the import agricultural products should be adjusted based on the national grand strategies and the distribution centers should be established for the main agricultural products needed to be import to improve the adjustment capacities.

Reinforce the Agricultural Technology Introduction. The modern agricultural talents and industrial clusters entrepreneurs with the international operation and management abilities should be introduced. The introduction of the key applied technologies, advanced technologies and patents of the advanced agricultural equipments, stock breeding, agricultural products' manufactures, processes, storages, logistics and sales should be supported. External scientific and technological achievements' demonstration zones should be established. Agricultural hi-tech industries should be cultivated faster. And the bottleneck problems of the modern agriculture development should be solved.

Set up Special Fund for Agricultural Foreign Cooperations. Appropriate subsidies should be offered to the enterprises to do the overseas early investigations, risk assessments, expert argumentations, greenfield investment, resource developments and cross-border mergers and acquisitions. the government should give full play to all kinds of enterprises, industry organizations actively carry out foreign direct investment and multinational management exploration and practice. Foreign exchange reserve should be used flexible.

\section{References}

[1] Y.Zhou: Research on the international competitiveness of Chinese and American agricultural products, Business Herald, 2016, No.1. In Chinese.

[2] L.L.Jiang: Study on the Mechanism and Countermeasure of improving international competitiveness of China's agricultural products from the perspective of structural optimization, Management world, 2016, No1, In Chinese.

[3] X.Z.Ii: Global Agricultural Products Trade and the International Competitiveness of China's Agricultural Products, Agricultural Economy, 2014, No.8. In Chinese

[4] H.Zhang: Research on the Countermeasures of Enhancing the Competitive Strategy of China's Export Agricultural Products, Agricultural Economy, 2016, No.4. In Chinese.

[5] X.J.Lei: Agricultural Investment and Foreign Trade of Agricultural Products in China (PH.D, Ningbo University, China 2014)

[6] B.R.Wan: Thoughts on Speeding up the Agricultural Competitiveness of our Country, Agricultural Economic Problems, 2016,No4. In Chinese.

[7] X.H.Zhang: An Empirical Analysis on the Impact of Agricultural Technological Progress on the International Competitiveness of Chinese, Agricultural Products, 2015, No.7. In Chese.

[8] S.Jayaswal,E.M.Jewkes: Price and lead time Differentiation, Capacity Strategy and Market Competition. International Journal of Production Research, 2016, No.54.

[9] Mahmoud El-Jafari: The International Competitiveness of the Palestinian Agriculture, 2015, No.12.

[10]Daniel E May Behavioural Drivers of Business Competitiveness in Agriculture, Agricultural Economics Review, 2015, No.16. 